Western New England University School of Law Digital Commons @ Western New England University School of Law

\title{
Challenging Gender in Single-Sex Spaces: Lessons from a Feminist Softball League
}

Erin E. Buzuvis

Western New England University School of Law, ebuzuvis@law.wne.edu

Follow this and additional works at: https://digitalcommons.law.wne.edu/facschol

Part of the Civil Rights and Discrimination Commons, and the Sexuality and the Law Commons

\section{Recommended Citation}

Erin E. Buzuvis, Challenging Gender in Single-Sex Spaces: Lessons from a Feminist Softball League, 80 L. \& CONTEMP. PROBS. 155 (2017).

This Article is brought to you for free and open access by the Faculty Publications at Digital Commons @ Western New England University School of Law. It has been accepted for inclusion in Faculty Scholarship by an authorized administrator of Digital Commons @ Western New England University 


\title{
CHALLENGING GENDER IN SINGLE-SEX SPACES: LESSONS FROM A FEMINIST SOFTBALL LEAGUE
}

\author{
ERIN E. BUZUVIS* \\ I \\ INTRODUCTION
}

In the small western Massachusetts city where I live, women's softball has been a summer tradition since the 1970s. The founders of our league, the Mary Vazquez Women's Softball League (MVWSL), started it as an intentionally feminist project, an antidote to male dominance of athletic opportunities and an effort to reclaim the athlete label from the exclusive domain of men. To this day, MVWSL retains both formal and informal rules to promote participation by those of diverse skills and abilities, an inclusion tactic as well as an accommodation to women's historical exclusion from the opportunities to develop athletic skills. The rules ensure that participation-and a result, community-is not threatened by the competitive aspect of the games themselves. For example, there are no league standings and any team who cares to know the score usually keeps track quietly. If a batter feels intimidated by the pitch, she has the prerogative to ask the pitcher to slow it down; pinch runners are liberally allowed to accommodate injuries and other running challenges. One team has a policy that forbids player-coaching from the sidelines and redirects constructive criticism to the post-game social hour. Another team identifies as "dry" so that nondrinkers are not alienated from off-the-field team functions. Every player strives to hit, run, catch, and throw to the best of her ability; but community is the centerpiece of the league, not the standings. ${ }^{1}$ MVWSL is that kind of league, and players are proud of its feminist origins and feminist quirks.

\section{Copyright $@ 2018$ by Erin E. Buzuvis.}

This article is also available at http://lcp.law.duke.edu/.

" Professor, Western New England University School of Law. When the author is not teaching, reading, or writing about gender and sport, she plays outfield for the Left Sox of the Mary Vazquez Women's Softball League in Northampton, Massachusetts.

1. Scholar-activist Pat Griffin published a memoir essay based loosely on her experience joining this very league in its early years. A competitive and self-described jock, Griffin experienced a bit of culture shock when she discovered that her new teammates eschew keeping score, engage in consensus coaching, sit next to their opponents on the same sideline, and end every game with a processing circle. See PAT GRIFFIn, Diamonds, Dykes, and Double-Plays, in SPORTSDYKES: STORIES FROM ON AND OFF THE FIELD (Susan Fox Rogers ed., 1994). Having already read this essay, I sought out the league immediately upon my own arrival in Northampton in 2006. I have found that the skill level and interest in winning has increased since the era Griffin wrote about, but we still sometimes share the sidelines with the other team. 
A few years ago, the matter of transgender inclusion forced MVWSL to revisit and redefine its commitment to feminism. ${ }^{2}$ Like other contemporary women's spaces, the league had stakeholders who were not immediately comfortable opening up the community to women who were not assigned female at birth, nor were they comfortable acknowledging that the community already included some who identify as something other than female. ${ }^{3}$ To these stakeholders, it was essential to restrict the league to a narrow definition of female participants in order to preserve it as a site of feminist resistance, safety, and empowerment. To others, the realization that the league did not expressly permit some teammates to freely acknowledge gender identities other than female conflicted with strongly-held beliefs about inclusivity and unity across queer identities. It was possible that adopting a trans-inclusive policy would compel some members to leave the league, but the absence of such a policy threatened the same thing.

In the end, the league worked through this identity crisis and reached a peaceful consensus around inclusion. During this period of evolution, I turned to scholarship for guidance and found that adult recreational sport was near-totally omitted from the broader scope of scholarly literature about transgender inclusion in sport. ${ }^{4}$ Appropriately, scholars and advocates have considered the

2. The issue arose gradually and in response to what appeared to be one player's physical and social transition over a couple of seasons. The presence of this player caused some to question how the league defined its eligibility. The league had an oral tradition of being open to those who are "female identified," but this meant different things to different people. Some thought this meant the league was open to anyone whose gender identity is female, including transgender women, but implicitly excluding trans men and non-binary/genderqueer players. Others thought this meant the league was open to anyone whose identity documents said female, which would include those transgender women who had changed their legal gender markers as well as those who do not identify as female but still have an "F" on their drivers' licenses.

3. The latter was more controversial, probably because the league was confronting the question of actual transgender participants who do not identify as female. Yet, this observation is consistent with one researcher's finding that lesbian softball leagues have more easily adapted to inclusion of male-to-female transgender athletes because such participation does not challenge deeply entrenched notions of the gender binary. See Ann Travers, Queering Sport: Lesbian Softball Leagues and the Transgender Challenge, 41 INT'L REV. SOC. SPORT 431, 441-42 (2006).

4. The literature in this area predominantly addresses scholastic, collegiate, professional, and Olympic sports. E.g., Erin E. Buzuvis, As Who They Really Are: Expanding Opportunities for Transgender Athletes to Participate in Youth and Scholastic Sports, 34 LAW \& INEQ. 341 (2016); Erin E. Buzuvis, Hormone Check: A Critique of Olympic Rules on Sex and Gender, 31 WIS. J.L. GENDER \& SOC'Y 29 (2013); Erin E. Buzuvis, Transgender Student-Athletes and Sex-Segregated Sport: Developing Policies of Inclusion for Intercollegiate and Interscholastic Athletics, 21 SETON HALL J. SPORTS \& ENT. L. 1 (2011); Sheila L. Cavanagh \& Heather Sykes, Transsexual Bodies at the Olympics: The Int'l Olympic Committee's Policy on Transsexual Athletes at the 2004 Athens Summer Games, 12 BODY \& SOC'Y 75 (2006); Jill Pilgrim et al., Far From the Finish Line: Transsexualism and Athletic Competition, 13 FORDHAM INTELL. PROP., MEDIA, \& ENT. L.J. 495 (2003); J.C. Reeser, Gender Identity and Sport: Is the Playing Field Level?, 39 BRITISH J. SPORTS MED. 695 (2005); Elliot S. Rozenberg, The NCAA's Transgender Student-Athlete Policy: How Attempting to be More Inclusive Has Led to Gender and Gender-Identity Discrimination, 22 SPORTS LAW. J. 193 (2015); Scott Skinner-Thompson \& Ilona M. Turner, Title IX's Protections for Transgender Student Athletes, 28 WIS. J.L. GENDER \& SOC'Y 271 (2013); Pat Griffin \& Helen Carroll, On the Team: Equal Opportunities for Transgender Student Athletes, NAT'L CTR. FOR LESBIAN RTS. \& WOMEN's SPORTS FOUND. (2010), http://www.nclrights.org/wp- 
role of transgender athletes in the contexts of Olympic, professional, and collegiate sports. But the issue of transgender inclusion is more likely to affect athletes in the recreational context because a significant number of adult Americans report playing sports for leisure, and many of them choose adult recreational leagues. ${ }^{5}$ Moreover, the academic debate over transgender inclusion at the Olympic, professional, and collegiate levels cannot be directly imported to the adult recreational context because recreational sports have a relatively stronger communitarian purpose and there is relatively less at stake in the outcomes of the contests themselves. Thus, this article seeks to start the conversation about transgender inclusion within adult recreational leagues.

II

\section{WHY WOMEN-ONLY SOFTBALL?}

Adult recreational sports comprise a diverse category. This article does not purport to examine it comprehensively. Rather, by addressing a narrow example (MVWSL), this article demonstrates that it is possible to customize a policy that defines inclusion in a manner consistent with a league or association's history, goals, and philosophy. This is particularly important because leagues are unlikely to find conclusive answers to this question by turning to public law. Even in states with laws that prohibit places of public accommodations from discriminating on the basis of gender identity, the application of such laws to single-sex spaces and activities like women's sports is still emerging. ${ }^{6}$ Furthermore, sports leagues may argue that they fall outside the realm of public accommodations law, either because they are protected by the First Amendment or because they are private associations. ${ }^{7}$ Either possibility means that leagues should examine their missions

content/uploads/2013/07/TransgenderStudentAthleteReport.pdf [https://perma.cc/FDG7-SVQR]. The work of Ann Travers on transgender athletes' participation in adult recreational leagues stands out as the exception. See TrAVERS, supra note 2; Ann Travers \& Jillian Deri, Transgender Inclusion and the Changing Face of Lesbian Softball Leagues, 46 INT’L REV. SOC. SPORT 488 (2011).

5. See Poll: Three in Four Adults Played Sports When They Were Younger, But Only One in Four Still Play, HARV. SCH. PUB. HEAlth (June 15, 2015), https://www.hsph.harvard.edu/news/pressreleases/poll-many-adults-played-sports-when-young-but-few-still-play/ [https://perma.cc/9XGAWVVG] (reporting that, of the three quarters of Americans who played sports as children, one quarter continue to play sports as adults).

6. See, e.g., CAL. Civ. Code $\$ 51$ (West 2016); Colo. Rev. Stat. § 24-34-601 (West 1993); HaW. REV. STAT. § 489-3 (West 2006); 775 ILl. COMP. STAT. 5 (2006); MASS. GEN. LAWS ANN. ch. 272 § 92A (West 2016); OR. REV. STAT. § 659A.400 (West 2014); 11 R.I. GEN. LAWS § 11-24-3 (1956).

7. To even reach the question of what a public accommodations law requires, the league would have to be considered public enough to fall within its scope. If it is, the question of transgender inclusion would be preempted by the question of whether such a league could permissibly exclude men because all state public accommodations laws ban discrimination on the basis of sex. State Public Accommodations Laws, NAT'L CONF. OF ST. LegiSlatURES (July 13, 2016), http://www.ncsl.org/ research/civil-and-criminal-justice/state-public-accommodation-laws.aspx [https://perma.cc/6TFY$6 \mathrm{WWG}$. Even if public accommodations law could restrict league rules, the league could argue that they are expressive associations with First Amendment rights to determine their own membership notwithstanding the public accommodations law. E.g., Apilado v. N. Am. Gay Amateur Athletic All., 792 F. Supp. 2d 1151, 1161-64 (concluding that the Alliance was an expressive association with the right to limit the number of heterosexual players). 
and expressive purposes to determine questions of membership, rather than seek answers from some external source like law.

To understand the challenge that transgender athletes pose to some women's sport contexts, it is necessary to understand the reasons why they exclude men in the first place. While much sex-segregation in sport is rooted in the perception that it is necessary to maintain competitive equity, this is not the only reason. Outside of the professional and amateur elite contexts, most people play sports for reasons that include social and communitarian benefits. Relatedly, womenonly sporting spaces are designed and maintained to cultivate a particular social experience and community.

\section{A. Women-Only Softball Builds Community}

Women join softball teams for the chance to enjoy physical recreation and to build communities with other women. ${ }^{8}$ In particular, lesbians in the midtwentieth century found softball and other team sports to be an essential context for self-discovery and community-building ${ }^{9}$ - not only among participants, but among spectators as well. In an era where prejudice, discrimination, and hostility forced the lesbian community to keep a low profile, the softball field and stands became the unspoken place where lesbians could meet each other.$^{10}$ Historian Susan K. Cahn explains how sporting spaces helped create lesbian social networks and community:

Since sport provided public space for lesbian sociability without naming it as such, or excluding women who were not lesbians, women who were unsure about, or just beginning to come to terms with, their sexual identity could explore different social and sexual possibilities without having to make immediate decisions or declarations. Gradually, often relying on unspoken communication, some of these women articulated a lesbian identity and joined in the process of forging broader social networks and a collective lesbian culture. ${ }^{11}$

Women's sporting spaces allowed athletic women, and particularly lesbians, to reclaim stigmatized qualities for women, like "aggressiveness, toughness, passionate intensity, strength, physicality, and competitiveness."12 Sport allowed women who valued and shared these ostensibly masculine qualities to have a place to exercise them in a place where they would be validated.

MVWSL operates in a town that was once referred to by Newsweek as "Lesbianville, U.S.A." "13 Accordingly, it is not terribly surprising that in the 1970s and 1980s, women's softball was a euphemism for lesbian. ${ }^{14}$ Some of the early

8. CAHN, infra note 19 , at 143.

9. Id. at 185 .

10. Id. at 189 ("In a day when there were few gay bars or other social institutions, sports opened up a space in which lesbians could gather and begin to forge a collective culture.").

11. Id. at 190.

12. Id. at 201.

13. Barbara Kantrowitz, A Town Like No Other, NewsweEK (June 20, 1993), http://www. newsweek.com/town-no-other-193714 [https://perma.cc/8GDY-UXCJ].

14. For this and other historical perspective, the Valley Women's History Collaborative has archived the transcripts of oral history research conducted on the league. Mary Vasquez Softball League History, 
teams restricted membership only to lesbians; in fact, one team was started by players who left another team in protest of its refusal to admit a straight player. The historic exclusion of non-lesbians was designed to ensure that the league provided safety and peace of mind to women who were closeted and marginalized elsewhere, allowing them to come together and enjoy the company of people with whom they shared a common bond. Today all teams in the league are welcoming of straight players, though lesbians are still probably the majority on every team. Still, even though the league is more diverse in this respect today, the fact that lesbian and queer players more than constitute a critical mass ensures that the league still functions as a site for lesbian or queer community. As evidence of this, the league intersects directly with political or other current events when LGBT issues are on players' minds - like the day the Supreme Court decided United States $v$. Windsor, ${ }^{15}$ when a player led her team in a champagne toast after the game. Or the game played the day after the shooting at the Pulse gay nightclub in Orlando, which the teams started only after holding hands with opponents in a moment of silence. These and other examples demonstrate how this softball league provides an important community for women, and particularly for lesbians.

\section{B. Women-Only Softball Challenges Patriarchal Values}

Before examining these reasons in greater detail, it should be acknowledged that there is potential for women's sport to either replicate or undermine patriarchal values that are transmitted through sport, sometimes even doing both at the same time. For instance, when a city's recreation department creates separate soccer leagues for girls and boys, it may do so in response to unchallenged assumptions that the girls will be less skilled or physically disadvantaged in a co-ed context. In so doing, the department constructs the very difference that might not otherwise exist. ${ }^{16}$ Even sporting structures that are not formally off-limits to the other sex may still represent de facto segregation, which is maintained through social norms and customs that are just as coercive. Little League Baseball does not technically exclude girls; it does not have to. Society effectively channels most girls away from baseball and into another sportsoftball-deemed its appropriate, female equivalent. ${ }^{17}$

These and other examples of coercive sex segregation in sport pave the way for differential treatment of men's and women's sports. Once sports are separated, disparities in media coverage, allocation of resources like coaching

VALLEY WOMEN'S HIST. COLLABORATIVE, http://www.vwhc.org/maryv.html [https://perma.cc/RVL888RT] (last visited Oct. 11, 2017).

15. 133 S. Ct. 2675 (2013) (holding that the Defense of Marriage Act, 1 U.S.C.S. $\S 7$, is unconstitutional).

16. EILEEN MCDONAgh \& LAURA PAPPANO, Pla Ying With THE Boys: Why SEPARATE Is NOT EQUAL IN SPORTS 15 (2008) ("In reality, sex-segregated policies construct sex difference, thereby articulating in athletic and public life the relative potency and status of what we mean by male and female.").

17. Jennifer Ring, Stolen Bases: Why American Girls Don’t Play Baseball 62 (2010). 
and facilities, and cultural affirmation operate to bestow greater privilege on male sporting contexts and participants, constructing them as deserving, normalized, and superior. Female sports are less visible, less supported, antinormalized, and inferior. These disparities may turn women off of sportmarginalizing them from the feelings of physical empowerment, interpersonal relationships within a team, and association with the positive attributes that society ascribes to athletes and athleticism. Men's physical dominance in sport, thus normalized, signals men's higher position on a social hierarchy that extends to any context where athletic traits like power, strength, action, and competence are measured.

On the other hand, women's sport has the potential to challenge the patriarchy, rather than replicate it. This is especially true in sporting structures that women have intentionally designed to reject the trappings of the masculine model of sport. As Marilyn Frye put it, "[t]he woman-only meeting is a fundamental challenge to the structure of power" just as "[t]he slave who decides to exclude the master from her hut is declaring herself not a slave." 18 Women have been carving out a sporting space of their own for much of history. In the twentieth century, female physical educators promoted athletic participation for female students in a structure separate from the varsity model that was gaining popularity for men in American secondary and post-secondary institutions of education. Today, many aspects of these programs-including their insularity, social focus, and limited scope-appear paternalistic and suggest that physical educators did not take women's sports seriously..$^{19}$ However, viewed in their historical context - which included a society suspicious of women's activity due to concerns about modesty, morality, and female fragility-their subversive nature is more easily recognized. In retrospect, female physical educators' historic resistance to the varsity athletics model appears progressive for its time because it emanated from the same concerns we hear today about the commercialization, disproportionate scale, and all-consuming nature of college, high school, and youth sports.

Despite its subversive and prescient attributes, the physical education model for women's sports also contributed to a negative association between femininity and so-called serious athletics. Women's participation in competitive, organized, team sports was an act of resistance to a society that still expected their athletic endeavors to be modest, occasional, and secondary to other interests. Softball, which flourished in working-class communities that were less invested in such

18. MARILYN Frye, Some Reflections on Separatism and Power (1977), in FOR LESBIANS ONLY: A Separatist Anthology 62, 68 (Sarah Lucia Hoagland \& Julia Penelope eds., 1992).

19. See Susan K. Cahn, Coming on Strong: Gender and SeXuality in TwentiethCENTURY WOMEN'S SPORT 24 (1994) (explaining that physical educators "carved out a separate realm of play in which women could gain the traditional benefits of sport-health, fun, 'sportsmanship,' and a cooperative ethos-without fear of sexual harm or the taint of masculinity"); MARY JO FESTLE, PlAYING NiCE: POLITICS AND APOLOGIES IN WOMEN'S SPORTS 11 (1996) ("Rather than building national champions in Olympic sports, college PE teachers instead emphasized sports that they thought would meet women's leisure needs in their postschool years, such as tennis, swimming, and golf."). 
Victorian notions, took hold and became the locus of an "embryonic women's athletic subculture."20

\section{Women-Only Softball Supports Feminist Values}

MVWSL did not only use women's softball as the means to foster community among lesbians and allies; it also used separatism to apply the feminist ideologies of its founding era, the 1970s, to the context of sport. This included radical feminism. In contrast to liberal feminism, which seeks equal opportunity within existing structures, radical feminism seeks to overhaul structures in ways that incorporate feminist values. Title IX, the law prohibiting sex discrimination by educational institutions, including in athletics programs, could be seen as a liberal feminist initiative - or having a liberal feminist effect-because it created a legal framework that opened the male-dominated sporting structures to women. Varsity sports were offered to women, the NCAA took over women's sports, and the same rules that governed men now applied to female athletes as well. ${ }^{21}$

At the same time, a radical re-envisioning of sport could also be seen in some of the women's leagues founded in that $\mathrm{era}^{22}$-including the MVWSL, which was created in 1976. The MVWSL may be considered radical because it instrumentally deployed separatism to "reclaim sport as a feminist activity" rather than simply opening up or replicating existing, male-dominated sporting structures for women. Women's sport reflects radical feminist principles when it retains jurisdiction and autonomy for women to lead, organize, and ensure that sport reflects women's values. According to sport scholar Susan Birrell, some of those values may include:

$[\mathrm{C}]$ hoosing process over product; valuing cooperation and competition as equally valid processes; emphasizing nurturant relationships among teammates and opponents; deemphasizing aggressiveness, rationality, and specialization; fostering a sense of the game as something the players create together; condemning the practices of psyching out or jeering at one's opponents. ${ }^{23}$

These values are reflected in the structure and the rules of MVWSL. Players choose process over product by emphasizing the games and not the outcomes. There are no standings, playoffs, or championships; consequently, there is no

20. CAHN, supra note 19 , at 144 .

21. When the NCAA offered championships for women's sports, women's sports gained access to resources and visibility that were not granted to them under the separate women's structure. However, this effective takeover drove the AIAW out of business, reducing opportunities for women to serve in positions of leadership at the intercollegiate level as well as within their home institutions. It also ensured that college sports would operate for both male and female students according to a male model. Differences that had defined women's sports as unique were erased. For example, the AIAW adhered to an amateurism principle that eschewed scholarships. Unlike the NCAA, it did not require athletes to use their four years of eligibility within a five-year period. See FeSTLE, supra note 19, at 288; YING Wushanley, Playing Nice AND Losing: The STRUggle FOR CONTROL OF WOMEN's INTERCOLLEGIATE ATHLETICS, 1960-2000 33-62 (2004).

22. Susan Birrell \& Diana M. Richter, Is a Diamond Forever? Feminist Transformations of Sport, 10 WOMEN's STUD. INT'L F. 395 (1987); Vicki Gabriner, Come Out Slugging, 2 QUEST 52 (1976); Nancy Theberge, Sport and Women's Empowerment, 10 WOMEN's STUD. INT'L F. 387 (1987).

23. Susan Birrell, Separatism as an Issue in Women's Sports, 8 ARENA REV. 21, 24 (1987). 
incentive to sacrifice the process of the game in the quest for the product of a better win-loss record. If the product mattered, a team would have incentive to stack its roster with better players; instead, teams welcome beginning players, distribute playing time equitably regardless of talent and experience, and even have specific rules to facilitate play between and among players of diverse skill. ${ }^{24}$ If the product mattered, a team would take a forfeit win over a team that doesn't have enough players on a given night. Instead, that team will offer their opponent extra players so that the game can go on.

These aspects of MVWSL also demonstrate that competition, though certainly present, does not eclipse other goals like cooperation, inclusion, participation, and encouragement to do one's best. Additionally, the league expressly prohibits taunting and jeering at opposing players and requires winning teams to preserve the dignity of losing teams by modifying their play when the score is lopsided..$^{25}$ The women-only aspect to the league helps all players reach their personal best by eliminating the tendency of co-ed softball to marginalize women in secondary positions ${ }^{26}$ and the paternalism that is reflected in special rules that presume that women are always the weaker players. ${ }^{27}$ Relatedly, the women-only aspect of the league mitigates the potential for stereotype threat to interfere with players' self-actualization on the field. ${ }^{28}$ Instead of being subjected to the dominance of male players - who may have capitalized on the better and more numerous opportunities they have received to cultivate superior skill-the

24. Rules, Regulations, Responsibilities, and Courtesies, MARY VAZQUEZ WOMEN'S SOFTBALL LEAGUE, Rule 17, www.maryvsoftball.org/rules [https://perma.cc/DX5P-TLK7] (last visited Oct. 11, 2017) ("If the pitch is too fast, the team rep or an individual player should speak to the umpire about it; she will then ask the other team to slow the pitch down.").

25. Id. at Rule 15 ("Watch your attitude. . . Don't heckle the other team ('She can't hit,' etc.). Sometimes teasing your friends can make them nervous while they are at bat. Be encouraging."); Rule 16 ("If a team has over ten runs and the other team has none, the winning team should have gracious sensitivity toward the losing team. Don't be condescending, etc. Consider a change of strategy: change players around, don't steal, etc."); the 1987 Rule ("Any behavior that interferes with the spirit or progress of the game, including but not limited to, abusive statements, unsportswomyn-like comments or endangering behavior, is prohibited. These actions will elicit a warning from the umpire to the team reps. The second violation will result in a forfeit by the offending team.").

26. Often, co-ed leagues will require an equal number of women in the batting order and in the field. In leagues that require equal number of women in infield, outfield, and battery positions, women will necessarily play first- and second- base, right- and short center- field, and catcher and rarely get to pitch or play the positions on the left side of the field where the balls are more regularly hit by right-handed batters. See, e.g., Faye Linda Waugh, The Boundaries of Difference: Negotiating Gender in Recreational Sports, 75 SOC. INQUIRY 527, 539-41 (2005) (explaining that cultural presumptions about skill and ability often cause such positional segregation).

27. Id. at 535 (referring, for example, to rules that encourage women but not men to walk).

28. Stereotype threat is "when knowledge of a negative stereotype about a social group leads to less-than-optimal performance by members of that group." The theory is usually applied to explain academic performances of racial groups, but it has been demonstrated to have application to athletic performance as well. Women are barraged with the message women are less athletic than men, in particular in the context of co-ed play where the rules reflect this very assumption. Applying the stereotype threat theory to women in sports would suggest that women could have a harder time playing their best in a co-ed context than if they were more insulated from the stereotype in an all-women's league. Sian L. Beilock \& Allen R. McConnell, Stereotype Threat in Sport: Can Athletic Performance Be Threatened? 26 J. SPORT \& EXERCISE PSYCHOL. 597, 597-609 (2004). 
only players in our league who get good hits and make good plays are women. The role-modeling by women athletes extends not only to players but also to fans and spectators. Players who bring their children to the games are necessarily raising them in a culture where female athleticism is visible and normalized.

The league's structure creates opportunities for women to lead because the commissioner and other leadership positions are all filled by members of the league. There are no coaches, hired or otherwise, and some teams even regulate the time, place, and manner of player-coaching out of sensitivity to power dynamic that such instruction can create. The league hires female umpires who serve as the designated decision-maker when it comes to the calls of the games. Players expect and appreciate umpires' efforts to be accurate as possible, and they rarely dispute calls. This deference, it should be stated, does not reflect or bestow power on the umpire; rather, it reflects the players' appreciation that the umpire's decisions are necessary to the progress of the game, and that their presence relieves players of the burdensome responsibility to determine calls themselves. Players do not dispute calls because they recognize that even bad calls allow the game to continue, whereas arguments disrupt play. For all these reasons, umpires in MVWSL serve clearly as facilitators of the game and not as power-holders.

In sum, MVWSL uses separatism to foster community among women who, while otherwise diverse, are similarly attracted to a predominantly lesbian community-either because they are lesbian, or because they relate to lesbian culture as women who are gender nonconforming as female athletes, or because they assume they will find compatible personal or political beliefs. MVWSL also uses separatism to compensate for the disparity in athletic opportunities, both in the past and today, by ensuring that women have the opportunity to play, to lead, and to organize. Finally, it uses separatism in the service of a radical feminist project-not to fit women into the dominant model of sport, but to create an alternative model that promotes certain feminist values.

III

\section{A TRANSGENDER THREAT?}

Are transgender athletes a threat to the purpose and objectives of a women's softball league like MVWSL? When players in the league discussed the issue in an effort to create a policy, players gave many reasons to explain their opposition to and concerns about inclusion. Most opposition fell into two categories: (1) concerns about competitive equity and (2) concerns about preserving a unique and intentionally exclusive community of women.

\section{A. Threat to Competitive Equity?}

Competitive equity concerns are rooted in the belief that transgender athletes have a physical and athletic advantage over nontransgender women. This belief, in turn, derives from generalized assumptions about the physical and athletic differences between men and women. Some assume that transgender women 
retain male physical characteristics consistent with their sex from birth. Similarly, some assume that transgender men have acquired male physical characteristics as a result of hormones - exogenous testosterone - taken to facilitate transition. In both cases, the competitive equity concern can be summarized this way: men are more athletic than women; transgender athletes are more like men than women; therefore, it is not a fair playing field when transgender athletes play with or against women. A derivation of this argument, which is more commonly expressed in MVWSL due to its equal emphasis on competition and participation, is that transgender athletes' physical and athletic advantages present safety risks to nontransgender women. ${ }^{29}$

Do transgender athletes compete at an advantage? There certainly are physical characteristics attributable to testosterone. An athlete who is assigned female at birth and starts taking testosterone later in life will develop larger muscles, a leaner body, and increased oxygen capacity that he did not have prior to transition. ${ }^{30}$ But these physical changes, though visually obvious, do not necessarily translate into immediate and automatic competitive advantages in sports for several reasons. First, physiology alone does not predict athletic performance. ${ }^{31}$ The sprinter with the higher concentration of type II (fast twitch) muscle fibers may have an advantage over a sprinter with less, but this factor alone does not guarantee his victory. The volleyball team with the tallest average height may have an advantage over a shorter team, but this advantage does not correlate with wins. We cannot isolate athletic performance to particular traits, sex-based or otherwise, because many exogenous factors contribute to athletic performance, including practice and training, intelligence, and even luck. In one study, boys and girls were found to have similar throwing ability when they used their nondominant arms; this suggests that training accounts for more athletic variation than sex does. ${ }^{32}$ We should therefore expect that men's and women's athleticism will become more similar with time, as women's access to and interest in sports continues to increase. Evidence of the closing of performance gap in

29. For example, a pitcher in MVWSL was questioned and criticized by members of the league when she chose to intentionally walk a masculine-looking woman who many perceive as a transgender man. Some expressed concerns for safety, suggesting that the intentional walk is a bona fide strategy in the game of softball justified in this case by the batter's reputation and tendency to hit the ball hard. Others argued that, while the intentional walk is a part of the game in general, it is not widely used in MVWSL because it inhibits participation. In fact, many long-time members were hard pressed to remember any other time a pitcher intentionally walked a batter. Thus, while the pitcher's concern about safety were genuine to her-as in, not a pretext for bias-it also appears that they were grounded in the perception or stereotype of transgender exceptionalism.

30. Michaela C. Devries, Do Transitioned Athletes Compete at an Advantage or Disadvantage as Compared with Physically Born Men and Women: A Review of the Scientific Literature, PROMISING PRAC. 4-6 (2008), http://www.caaws.ca/e/resources/article.cfm?id=2519 [https://perma.cc/GYC5-7GGZ].

31. Id. at 15 .

32. E.g., Collette Dowling, The Frailty Myth: Women Approaching PhysicAl EQUALITY 65 (2000) ("[P]ractice is what gave boys superior throwing skills. If gender differences in performance were, in fact, 'strongly related to biological factors,' these researchers argued, 'then gender differences should persist when children throw with their nondominant arm.'”) 
certain sports like distance running suggests that this is already happening. ${ }^{33}$ It therefore makes little sense to exclude transgender athletes based on the perception of sex-based physiological advantages.

Second, transgender athletes do not necessarily have a competitive advantage over nontransgender women because there is already a natural variation among women when it comes to size and strength. While men generally tend to be bigger and stronger than women, this is not always the case. Some women are bigger and stronger than some men, and society does not exclude the nontransgender outliers from participating in women's sports at any level, not even for reasons related to safety. For one reason, we welcome the contributions they make to the sport. In softball, for example, bigger and stronger women are often the ones most capable of hitting to the outfield, and beyond. When this happens, the player and her teammates celebrate. For another reason, whatever risk to safety that bigger and stronger players pose to others is a tolerable risk; not only because it is offset by the benefits they bring to the game, but because it is not really any greater than the risk inherent in the game. In softball, there is always a lowprobability risk of danger no matter who is involved in the play. A big, strong player might swing away and drive the ball into the pitcher, an infielder, or spectator sitting out of bounds. But it is just as likely that an average-sized batter will hit the pitcher or hit a foul ball into the stands; similarly, an infielder of any size or skill level could accidentally strike a base-runner with an errantly-thrown ball-or even an accurately-thrown one. Given this even spread of risk all players assume when they enter the game,$^{34}$ there is no discernable reason to exclude bigger, stronger players for reasons related to safety. ${ }^{35}$ Therefore, if the concern of allowing transgender women or transgender men into women's sports is that past or present exposure to testosterone has created bigger or stronger bodies, it makes little sense to single out their bigger and stronger bodies when we accept the bigger and stronger bodies of their natal female counterparts.

A third source of doubt on the myth of transgender exceptionalism applies particularly in the context of team sports, where it is even more difficult to isolate

33. See Cavanagh \& Sykes, supra note 4, at 83 (citing David Adam, Why Women Could Be Faster Than Man Within 150 Years, GUARDIAN (Sept. 30, 2004)) (describing "researchers at Oxford University who attempted to analyze the decreasing gap between male and female athletic achievement" who "predicted that sometime after 2064 women will be out-running men at certain track events").

34. Not only do players assume this risk, most also make the personal choice to forego the use of safety equipment that would mitigate this risk, like pitchers' masks and batting helmets. For this reason, it is difficult to accept stated concerns about safety as neutral, because they only come up in the context of our debate about transgender inclusion.

35. If it were, then co-ed sports in general would be deemed too dangerous to play. Instead, they are quite common. Indeed, courts have rejected that generalized concerns about safety are grounds for excluding girls from Little League and other sports. E.g., Fortin v. Darlington Little League, 514 F.2d 344, 350-51 (1st Cir. 1975) ("We conclude that the court's stated reason for finding Darlington's exclusion of girls 'rational'-namely, that injury will undoubtedly occur due to the physical differences between boys and girls - is unsupported."); Hoover v. Meiklejohn, 430 F. Supp. 164, 169 (D. Colo. 1977) ("The failure to establish any physical criteria to protect small or weak males from the injurious effects of competition with larger or stronger males destroys the credibility of the reasoning urged in support of the sex classification."). 
an individual player's physicality as the source of a competitive advantage for the team. One strong player cannot win a game that relies on teamwork and cooperation. Relatedly, a sport that involves a variety of skills, like softball, also dilutes the potential for an individual with a particular skill to dominate the game. A player with superior strength may be able to hit the ball far, but so what? A base hit is a base hit, whether it drops in the outfield or is well-placed between the short stop and infielder playing second base. Nor does superior strength necessarily accompany the hand-eye coordination, running speed, or strategic thinking that is necessary for strength hitting to be reflected in the score.

Finally, even if male physicality produced a demonstrable competitive advantage over cisgender women, transgender athletes do not warrant exclusion on the same grounds that cisgender men warrant exclusion. First, transgender is an umbrella term that incorporates many individuals who do not identify with the sex assigned at birth but do not necessarily identify as the opposite sex either. Some transgender individuals, including those who are female-bodied but not female-identified, may have no desire to ever undergo a hormonal transition. Moreover, among those who do wish to transition in the future, some may be waiting due to financial considerations, additional self-discovery, or other reasons. A league with a policy that requires players to identify as female excludes such players to whom no arguments about physical competitive advantage can apply. Even transitioned or transitioning female-to-male athletes do not become the physical equivalent of cisgender men. A female-to-male transsexual athlete may use testosterone to increase his musculature, leanness, and oxygen capacity to levels similar to nontransitioned men, ${ }^{36}$ but testosterone will not give him other characteristics deemed athletically advantageous, like height or bone mass. Similarly, a male-to-female transsexual athlete may be taking female hormones (estrogen), which contributes to characteristics deemed disadvantageous, like adipose tissue, as well as androgen-blockers that will neutralize the effect of testosterone on her muscles. ${ }^{37}$ Her height may not be affected by this hormonal transition, but having less muscle and a larger body could be a physical disadvantage compared to nontransgender women. Thus, the assumption that transgender athletes have similar physical attributes to men is particularly misplaced when applied to transgender athletes who are femalebodied, not female-identified, and not transitioning; it is weak when applied to transitioned/transitioning male-to-female and female-to-male athletes.

\section{B. Threat to Women's Community?}

Another set of objections to transgender inclusion reflects a concern that their presence would make the league no longer a women's only league. The issue of transgender inclusion applies differently to MVWSL than it does to other sporting contexts where community-building is not an essential goal because it

36. Devries, supra note 30, at 4-6.

37. Id. 
raises arguments about community as well as competitive equity. It does, however, make the issue similar to other separatist enterprises outside the context of sport that have confronted the question of transgender inclusion, like the Michigan Womyn's Music Festival ${ }^{38}$ and various women's colleges. ${ }^{39}$ Given that people exclude others all the time for reasons that are not invidious or discriminatory, many ask what is wrong with carving out one little space in this world to promote a community of women-identified, women-born women?

For example, some players in MVWSL questioned: If we do not require players to identify as female, what separates this league from any other co-ed league? Others expressed concern that if the league opened up to transgender players-or, more accurately, permitted current female-bodied players to come out about gender identities that are something other than female-then it would no longer be able to function as safe space, as a space of resistance and respite from the patriarchy that exists outside the league in the real world. Whichever tact, most opponents to transgender inclusion emphasized the importance of a common, shared experience as female women as a cornerstone of community. Opponents viewed transgender participants as incompatible with this community, lacking either the past or the present connection to female identity and expression.

What is the shared experience of being a woman? Today more than ever, women are as diverse from each other as women are different from men. MVWSL has long since abandoned the lesbian-separatist character of its founding; today's members are diverse with respect to not only sexual orientation, but also with respect to race, national origin, class, profession, age, and athletic experience and ability. Thus, those who advance the shared experience line of thinking do not really mean to suggest that women will necessarily have a common experience with each other by virtue of being women. Rather, they assert that participants are all excluded from male privilege in many socially salient contexts - professionally, financially, educationally, athletically. Everyone therefore has a stake in women's softball as resistance against the

38. The Michigan Womyn's Music Festival was an annual week-long music festival that began in 1976 (the same year as MVSL) and was known for its women-only policy that applied to organizers, attendees, and musicians alike. Though its founder and organizer did not specify reasons for its closure in 2015, the festival had become controversial for its position of exclusion of transgender women causing some high-profile musicians and sponsors to boycott the festival. Trudy Ring, This Year's Michigan Womyn's Music Festival Will Be the Last, AdVOCATE MAG. (April 21, 2015), https://www.advocate.com/michfest/2015/04/21/years-michigan-womyns-music-festival-will-be-last [https://perma.cc/S8LC-CZWD].

39. For example, Mount Holyoke College is open for admission to any qualified student "who is female or identifies as a woman, which includes those assigned female sex at birth regardless of their gender identity, as well as those with a female gender identity, regardless of their sex assigned at birth." Admission of Transgender Students, MOUNT HOLYOKE C., https://www.mtholyoke.edu/ policies/admission-transgender-students [https://perma.cc/WA5C-L47B] (last visited Oct. 11, 2017). Mills College has a similar policy, though it excludes those transgender students who have legally become male prior to applying. New Policy Clarifies 'Female' for Mills College Admission, SF GATE (Aug. 21, 2014), http://www.sfgate.com/education/article/New-policy-clarifies-female-for-Mills-College-5699337.php [https://perma.cc/CUT7-3LGH]. 
patriarchy-(re)claiming their athleticism and connecting with their bodies, providing themselves and their larger community with examples to undermine the paradox of female athleticism, and promoting a feminist alternative to the male model of sport.

If the shared experience as women is rooted in gender subordination, and the shared objective is to promote a sporting space that resists, rather than promotes, the patriarchy, then transgender athletes who self-identify as part of this community should be welcome. Transgender women may have had access to male privilege by virtue of having been perceived male for some or much of their lives, but documented evidence of discrimination suggests that transgender women abandon their male privilege by transitioning to the subordinated sex. For example, one study of transgender discrimination in the workplace shows that transgender women sacrifice up to one-third of their income upon transition, owing to the intersection of trans- and sex-discrimination in the workplace with respect to salaries, hiring, and termination, and other terms and conditions of employment. $^{40}$

Nor do transgender men level up their male privilege when they transition. Like women - transgender and cisgender alike-transgender men experience discrimination, harassment, and violence due to their transgender status. Even for those who experience new access to privilege by virtue of transition, usually as a result of passing as male, it is not necessarily a privilege equivalent to that bestowed on cisgender men. Again, workplace discrimination provides an example that can symbolize power and privilege in other contexts as well. Evidence suggests that while transgender men are sometimes better situated in the workplace after their transition than before, they are still generally disadvantaged in terms of salary compared to cisgender men. ${ }^{41}$ One explanation for this is that sex-based wage discrimination is prevalent in the workplacefemale workers earn less than their male counterparts because they are often hired on less favorable terms. If workers' pay increases as percentage of their existing salaries or wage rates, the overall income gap between the sexes increases over time. A transgender man might receive access to some male privilege in the workplace after transition, like a promotion, or a better raise than he would have received as a woman. However, as long as his salary is still calculated as a function of his existing salary, it will never catch up with that of his cisgender male counterparts. Compounded over a lifetime, and taking into account the pay discrimination he experienced as a woman, this transgender man will not earn what he would have earned if he had been assigned male at birth.

Money is not the only way to measure power and privilege, but it is often a proxy for power, and it can also serve as an example for privilege that is more difficult to see and measure, like male privilege in sport. A transgender man may be welcome into the sporting world of men, for example, and invited to join a

40. Ann C. McGinley, Erasing Boundaries: Masculinities, Sexual Minorities, and Employment Discrimination, 43 U. MICH. J.L. REFORM 713, 748 (2010).

41. Id. 
men's softball league. But having grown up without this access-maybe his town effectively or formally excluded girls from Little League, or his parents shunned girls' participation in athletics - he will still operate at a disadvantage relative to nontransgender men. This may reflect in inferior knowledge or competence that could hinder his acceptance and ability to participate on equal terms. If the softball community of women is defined by the criteria of shared experience, such an individual seems to qualify.

Other players suggested that in order to ensure that the league functioned as safe space for women, it should include all athletes, transgender or otherwiseas long as they identify as female. Such a policy would include transgender athletes who have transitioned from male to female, because they identify as women, but it would not include individuals who are assigned female at birth but identify either as male or nonbinary. When pressed, many who draw the line at "female identified" admit that they do not intend to exclude those assigned a female sex at birth who are not transitioning, regardless of the gender identity. This suggests a primary concern that testosterone taken by transitioned/transitioning female-to-male transsexuals would taint the women's only environment.

When considering this possibility, it is necessary to keep the scope of it in perspective. First, transitioned/transitioning female-to-male transsexuals are a subset of the transgender population, which is already an extreme minority. Moreover, many transitioned/transitioning transgender men will not self-select into women's softball because doing so could undermine their efforts to pass or to fully experience their gender identity as a nontransgender man, if that is their reality. A rule that includes transitioned transgender men by its terms-like a definition of woman that includes "anyone who was born female OR currently identifies as such" - is not likely to visibly change the content of the league significantly. Instead, it validates transgender participants who are, more likely, nontransitioning, and ensures that the league is a safe space for all those exploring or wishing to be out about their gender identities. This idea of a safe space should resonate with those who established leagues as a haven for all those exploring or wishing to be out about their sexual orientations..$^{42}$ Moreover, given that many trans men and nonbinary individuals have identified as lesbians in their past, it would be inconsistent for a league that was founded in part to provide safe space to lesbians to exclude a subset of that community.

On the other hand, a rule that singles out testosterone as the basis of exclusion can potentially undermine, or at least be read as inconsistent with, the feminist purposes of women's only space. It reinforces stereotypes and gender differences and female inferiority, which some argue are reinforced when sports organizers insist on a strict segregation by sex..$^{43}$ Those who deploy such a reductionist and

42. See CAHN, supra note 19, at 190 ("[C]oming out as a lesbian often meant fighting an extended battle against loneliness and self-hatred. Lesbian athletes reported that the sports world was important precisely because it allowed them to pierce the isolation and meet others 'of a kind."').

43. MCDONAGH \& PAPPANO, supra note 16, at 16 (explaining that sports segregation in non- 
paternalistic criteria for exclusion ally themselves with conservative proponents of gender verification policies - which belittle female athletes by conveying the sentiment that extremely successfully woman athletes must in fact be male. ${ }^{44} \mathrm{It}$ is also antifeminist to restrict the autonomy of others to choose for her/himself at what point they no longer find community in women's softball.

Those transgender men who would seek to participate in women's softball during or after transition may be seeking to preserve their connection to a community of women in general or lesbians in particular, and to keep their identity as transgender visible and salient. Both objectives are resistant and radical, as they foreground gender nonnormativity and present a visible challenge to the outdated notion of the gender binary that is also the basis of oppression for many nontransgender women who fail to conform with gender stereotypes. The presence, even theoretical presence, of transitioned transgender men also conveys confidence that the feminist principles of a women-only league are enduring and are not threatened by the possibility that the community could expand to include those with either a past or a present connection to a female gender identity. Transgender inclusion will not change a league's brand of softball from one that is process-oriented and collaborative to one that is competitive and hierarchical. It will not result in replicating the male model of sport, or surrendering to the privileged class the leadership and participation opportunities that a women-only league provides.

\section{IV \\ CONCLUSION}

MVWSL added the following provision to the league rules at the end of the 2013 season:

The Mary V League is an inclusive women's league. Those eligible to participate include: (a) Those individuals who sincerely and consistently identify as female, regardless of their sex assigned at birth; AND (b) Those individuals who were assigned a female sex at birth, regardless of their present gender identity, so long as they feel that membership in women's community is meaningful and appropriate for them. Players will determine for themselves whether they are qualified for membership under either (a) or (b). Players' self-determination will not be second-guessed. Teams remain empowered to determine their own membership, within these outer limits. ${ }^{45}$

Though the issue started as a contentious one, the adoption of the policy seemed to end rather than advance the controversy. To my knowledge, no one quit as a result of the policy or in response to the small but noticeable increase in gender-identity diversity within the league. Perhaps the process by which the

contact sports "is not rooted in physical group differences between the sexes. Rather, it comes from the pervasive assumption that women are just plain inferior to men in any sports competition, including card and board games").

44. See Buzuvis, Hormone Check, supra note 4 (outlining the International Olympic Committee's historical policies on sex tests and athlete qualification); Laura A. Wackwitz, Verifying the Myth: Olympic Sex Testing and the Category “Woman,” 26 WOMEN's STUD. INT'L F. 553 (2003) (describing Maria Patino's successful challenge of the sex test that led to her disqualification from Olympic competition).

45. MARY VAZQUeZ Women's SoftBall LeAgue, supra note 24, at Rule 18. 
policy was enacted contributed to the harmony that has since ensued. It was voted on at the end of the season so that teams could take the summer to discuss the proposed policy. The meeting at which it was considered was called only for this purpose, so there were no time constraints on a full and fair discussion. The meeting was facilitated by a respected former member of the league so that proponents of the policy were not also the same people running the meeting. And, in contrast to usual league business meetings to which each team sends one representative, the entire league was encouraged to attend this meeting. Thus, through these safeguards, the league adopted a fair process, designed to amplify and make room for all constituents' opinions.

Yet the substance of the policy is another reason for the happy ending here. MVWSL's policy, like the process that brought it about, was based on internal principles and values rather than external ones. For instance, unlike other sport contexts that separate the sexes because of stereotypes about women's athletic inferiority, MVWSL has other, cultural and communitarian reasons for limiting participation to women. Fittingly, it therefore rejected any sort of rule that operates to exclude members based on the presence of male hormones which are, albeit in an overly reductionist manner, credited for men's superior athletic talents. The MVWSL policy respects the league's core lesbian constituency by providing individuals with the freedom to openly acknowledge a gender identity that has or is evolving from lesbian to something else. And, it reflects the league's founding, feminist principles by refusing to define for others the suitability of women's community. The league's feminist foremothers would likely be pleased that the policy helps establish our version of sport as something alternative to the prevailing male model.

While this article has examined the sometimes uneasy alliance between feminism and transgender inclusion in the context of one softball league, the ideas herein can apply to other sporting contexts. In general, leaders of independent recreational leagues and associations in sports that use sex as a criteria for eligibility or other purposes - such as ensuring gender balance in coed sports-are encouraged to address the issue of transgender inclusion, recognizing both the power and the opportunity that they have to create policies that work for them. Rather than replicate the policies of Olympic, collegiate, or professional sport, these recreational leagues should engage in a value-driven process of self-determination. To this end, most leagues will find it appropriate to consider communitarian goals alongside other objectives related to the competitive outcomes. The stronger the role of community, the less important it is for eligibility standards to incorporate physical characteristics like hormones or anatomy. Although such characteristics were believed to be relevant to ensure competitive equity, they could operate in practice to exclude some transgender women as well as transitioning trans men from women's sport - or from women's roles in co-ed sport. Communitarian values may additionally lead leagues to determine, as MVWSL did, that gender identity should not be the sole criteria for eligibility because it excludes too many people with significant and meaningful ties to women's community that they fostered after being assigned 
female at birth. This last consideration may be particularly relevant to women's sports like softball, which have historically served an important role in fostering a lesbian community that has incubated many nonbinary and trans-identified individuals.

Beyond the context of adult recreational women's sports, other sporting contexts that separate players by sex would benefit from the values-driven process of determining who is eligible in each category, or for that matter, whether separation is necessary to promote the objectives of the leagues. For example, youth sports leagues may determine that objectives like character development, skill-building, and growing the sport warrant maximizing inclusion to the greatest extent possible, leading to removal of sex and gender altogether as criteria for participation. In the realm of scholastic sports, where segregation is arguably necessary to maximize participation, ${ }^{46}$ policymakers should consider the educational value to students when diverse participants coexist within gender categories, and therefore seek to define eligibility within those categories as broadly as possible. ${ }^{47}$

Sport is a powerful social force because of its capacity to influence cultural norms, values, and practices. Too often, however, the high-profile professional and Olympic sports are the ones that exercise this power, transmitting values like commercialism, nationalism, and elitism. Stakeholders in other sport contexts, like education and recreation, need not cede their own power to answer for themselves questions about gender and inclusion, and in the process to signify other values, like community, that are strengthened by sport.

46. Whether women's interests are served best by separate or co-ed sport is a complex question that is beyond the scope of this article. Here, it is sufficient to recognize that the most compelling justification for offering separate athletic opportunities for girls and women is to ensure their athletic opportunity as a remedy for the history of exclusion and suppression of women's interest in sport. See, e.g., DEBORAH L. BRAKE, GETTING IN THE GAME: TITLE IX AND THE WOMEN's SPORTS REVOLUTION 16-17 (2010).

47. Buzuvis, Hormone Check, supra note 4, at 43-56 (discussing the educational value of transgender inclusion in interscholastic sports). 